\title{
A case of unsuspected leiomyosarcoma diagnosed following laparoscopy-assisted vaginal hysterectomy performed for presumed myoma after GnRH treatment
}

B. Dilbaz $\cdot$ E. Ozkaya $\cdot$ S. Dilbaz

Published online: 20 March 2008

(C) Springer-Verlag 2008

Erratum to: Gynecol Surg

DOI 10.1007/s10397-008-0372-3

The authors were presented in the wrong order.

The list should have been as follows:

Dr. Berna Dilbaz, Dr. Enis Ozkaya, Dr. Serdar Dilbaz

The online version of the original article can be found at http://dx.doi. org/10.1007/s10397-008-0372-3

B. Dilbaz $\cdot$ E. Ozkaya $\cdot$ S. Dilbaz $(\bowtie)$

Ankara Etlik Maternity-Endoscopic Surgery,

Mithatpasa Caddesi, 59/3, Kizilay,

Ankara 06420, Turkey

e-mail: sdilbaz@hotmail.com 